\title{
Dampak Pembelajaran Online di Tengah Pandemi Covid-19 Terhadap Proses Pembelajaran Metode Yanbu'a di Kelas 2 MI At-Taqwa Bondowoso
}

\section{Fatia Inast Tsuroya}

Pascasarjana Universitas Islam Negeri Sunan Kalijaga Yogyakarta, Indonesia fatiainastsuroya@gmail.com

\section{Abstrak:}

Tujuan dari penelitian ini adalah untuk mengidentifikasi dan mendapatkan informasi mengenai dampak dari pandemi Covid-19 terhadap proses pembelajaran al-Qur'an dengan metode Yanbu'a DI kelas 2 di MI At-Taqwa Bondowoso. Penelitian menggunakan metode studi kasus eksplorasi dan pendekatan penelitiannya menggunakan metode studi kasus kualitatif yang digunakan untuk mendapatkan informasi kendala dan akibat dari pandemic COVID-19 terhadap kegiatan proses belajar mengajar di MI At-Taqwa Bondowoso. Ukuran sampel didasarkan pada pencapaian kedalaman dan kekayaan deskripsi. Menurut Guetterman, ukuran sampel bukan masalah opini representative dan pandangan, tetapi lebih merupakan masalah kekayaan informasi. Hasil dari penelitian ini adalah peneliti menemukan beberapa problematika dan kendala yang dialami oleh peserta didik dan guru kelas dalam kegiatan belajar mengajar online, antara lain: siswa tidak aktif untuk menyetorkan hasil bacaan yanbu'a dikarenakan adanya kendala jaringan, tidak adanya kuota, siswa tidak memiliki alat komunikasi atau handpohne sendiri, semangat siswa dalam belajar mulai menurun oleh karenanya tujuan dan target yang ingin dicapai oleh MI At-Taqwa bondowoso seperti cita-cita semula adalah siswa mampu membaca al-Quran dengan baik dan benar antara lain berupa makhorijul huruf, sifat-sifat huruf dan fashohah yang tepat banyak mengalami kendala akibat dari pembelajaran online.

Kata Kunci: Metode Yanbu'a, Pembelajaran Online, Pandemi Covid-19 


\section{Abstract:}

The purpose of this study was to identify and obtain information about the impact of the Covid19 pandemic on the learning process of the Koran using the Yanbu'a DI method in grade 2 at MI At-Taqwa Bondowoso. The research used an exploratory case study method and the research approach used a qualitative case study method which was used to obtain information on the constraints and consequences of the COVID-19 pandemic on teaching and learning activities at MI At-Taqwa Bondowoso. Sample size is based on attainment of depth and richness of description. According to Guetterman, sample size is not a matter of representative opinion and views, but rather a matter of information wealth. The results of this study were that the researchers found several problems and obstacles experienced by students and class teachers in online teaching and learning activities, including: students were not active in depositing their reading results due to network constraints, no quota, students did not have communication tool or handpohne itself, the enthusiasm of students in learning begins to decline, therefore the goals and targets to be achieved by MI At-Taqwa Bondowoso are like their original ideals, that students are able to read the Koran properly and correctly, including in the form of letters, characteristics Characteristics of letters and proper fashohah experience many obstacles as a result of online learning.

Keywords: Yanbu'a Method, Online Learning, Covid-19 Pandemic

\section{Pendahuluan}

Saat dikabarkan sejak Desember 2019 bahwa virus corona yang berasal dari Cina telah masuk ke Indonesia dan WHO mengkonfirmasi bahwa wabah ini merupakan pandemi global yang proses penularannya sangatlah cepat. Data terkini menunjukkan bahwa jumlah kasus virus corona di seluruh dunia saat ini telah lebih dari 43 juta, dan masih terus bertambah. Berdasarkan data Worldometers, Senin (26/10/2020) pukul 17.30 WIB, total kasus Covid-19 secara global adalah 43.404.812. Dari jumlah tersebut, sebanyak 31.934 .700 kasus telah dinyatakan sembuh, sementara 1.159.830 kasus berakhir dengan kematian. Di Indonesia, berdasarkan data Satgas Covid-19 per Senin (26/10/2020), terdapat 392.934 kasus virus corona. Sebanyak 317.672 kasus Covid-19 di antaranya telah sembuh, sedangkan 13.411 kasus lainnya berakhir kematian. ${ }^{1}$

${ }^{1}$ https://www.kompas.com/tren/read/2020/10/26/190100765/peringkat-indonesia-di-dunia-terkait-covid19--total-kasus-kesembuhan-dan?page $=$ all 200 | IQ (Ilmu Al-qur'an): Jurnal Pendidikan Islam| Volume 3 No.02 2020 
Data diatas membuat Indonesia mengambil keputusan untuk memberlakukan prinsip social distancing dengan tujuan untuk memutus rantai penyebaran virus dan ini juga berlaku terhadap kebijakan pendidikan di Indonesia, dengan ini pendidikan di Indonesia juga mengalami perubahan sistem pembelajaran yang berbeda dari sebelumnya yakni pembalajaran di laksanakan secara daring/online baik dari tingkat pendidikan usia dini hingga tingkat perguruan tinggi. Sebagaimana Kementerian Pendidikan dan Kebudayaan juga mengeluarkan surat edaran No. 4 Tahun 2020 terkait pelaksanaan pendidikan pada masa Covid-19 ini, di mana pelaksaan Ujian Nasional (UN) tahun akademik 2019/2020 resmi ditiadakan dan sekolah melaksanakan proses belajar dari rumah (Pusdiklat Kemendikbud, 2020). ${ }^{2}$ Begitupun dengan MI At-Taqwa Bondowoso juga melakukan penyesuaian pembelajaran dalam rangka mencegah penyebaran virus Covid-19 dilingkungan sekolah.

Salah satu sistem pembelajaran online yang dilaksanakan oleh MI At-Taqwa adalah pembelajaran metode Yanbu'a (Thoriqoh baca tulis dan menghafal al-Qur'an). Metode ini dipilih oleh MI At-Taqwa dengan tujuan untuk meningkatkan kemampuan baca-tulis al-Qur'an pada siswa. Sehingga menurut Isman proses pembelajaran daring ini dapat memanfaatkan jaringan internet/online. Adapun kelebihan sistem pembelajaran daring adalah keleluasaan waktu belajar, siswa dapat belajar kapanpun dan dimanapun. Jadi, siswa tidak perlu lagi khawatir karena dengan daringpun siswa dapat berinteraksi meskipun tidak bertemu langsung atau dengan jarak jauh. Beberapa aplikasi yang dapat digunakan oleh guru dan siswa MI AtTaqwa yang telah disepakati bersama guru dan siswa antara lain: telepon atau live chat, google class room, dan whatsapp group. ${ }^{3}$ Dengan Metode pembelajaran seperti ini adalah sebuah bentuk kongkrit dari inovasi pendidikan untuk menjawab tantangan dari perubahan dan perkembangan zaman, sehinga menjadi kewajiban bagi Guru MI At-Taqwa untuk meningkatkan kualifikasi akademik, kompetensi dan upaya-upaya membagun sinergitas sebagai pendidik profesional dengan harapan agar guru MI At-Taqwa bisa melakukan perannya sesecara profesional. ${ }^{4}$

Kendati demikian proses pembelajaran yang memanfaatkan internet sebagai media pembelajaran dan model pembelajaran yang variatif, tidaklah berjalan dengan baik dan sesuai

\footnotetext{
${ }^{2}$ Muhammad Taufiqurrahman, "Perkuliahan Daring Mata Kuliah Ilmu Pendidikan Islam Pada Masa Darurat Covid-19”, Ta'dibuna: Jurnal Pendidikan Islam, Vol. 9, No. 2 (Oktober 2020), 214.

${ }^{3}$ Halim Purnomo, Firman Mansir, Tumin, Suliswiyadi, "Pendidikan Karakter Islami Pada Online Class Management Di SMA Muhammadiyah 7 Yogyakarta Selama Pandemi Covid-19" Jurnal Tarbiyatuna, Vol. 11 No. 1 (2020), 92.

${ }^{4}$ Abd. Halim Soebahar, Matriks Pendidikan Islam (Yogyakarta: Pusataka Marwa, 2009), 192.
} 
apa yang diharapan. ${ }^{5}$ Karena tidak bisa dipungkiri pula bahwa keberhasilan pembelajaran juga tergantung dari karakteristik peserta didiknya. Sebagai mana yang dikatakan oleh Nakayama bahwa dari seluruh literature dalam pembelajaran, tidak semua siswa akan mencapai hasil dengan baik dalam pembelajaran online. Ini dikarenakan faktor lingkungan belajar dan karakteristik dari siswa itu sendiri sangatlah berpengaruh. ${ }^{6}$ Karena sejauh ini, sistem pembelajaran daring belum pernah dilaksanakan secara bersamaan diseluruh dunia terlebih juga di indonesia. maka, dalam proses pembelajaran daring, seluruh elemen pendidikan diwajibkan untuk mampu memfasilitasi dan melakukan inovasi pembelajaran yang menyenangkan agar siswa tetap aktif dan bersemangat dalam belajar meskipun tanpa melalui tatap muka secara langsung. ${ }^{7}$

Kegiatan pembelajaran yang dilakukan dengan sistem online tersebut mendapat respon yang beragam dari masyarakat, mulai yang pro dan kontra. Pro dan kontra yang tengah terjadi ditengah masyarakat, semua ini tidak terlepas dari persoalan kesiapan fasilitas pendukung kegiatan belajar mengajar dengan sistem online mulai dari jenjang pendidikan usia dini hingga perguruan tinggi, seperti kesiapan teknologi informasi dan komunikasi, sumber daya manusia dan fasilitas pendukung. ${ }^{8}$ Begitupun dengan permasalahan akses internet dan jaringan telah menyita perhatian yang serius bagi semua pihak. Mulai dari instansi pendidikan, pemerintah daerah maupun pusat, pengajar dan orang tua, untuk menyediakan layanan akses internet yang memadai agar proses pembelajaran online berjalan dengan maksimal. Karena sebagus apapun flatform pembelajaran online, namun tanpa didukung dengan jaringan internet, dampaknya tentu kurang optimal.

Tujuan dari penelitian ini adalah untuk mendapatkan informasi mengenai dampak pembelajaran online di masa pandemi COVID-19 terhadap proses pembelajaran metode yanbu'a di kelas 2 MI At-Taqwa bondowoso. Mengapa pembelajaran online di masa pandemi COVID-19 menjadi kurang efektif terhadap proses pembelajaran metode yanbu'a di kelas 2 MI At-Taqwa bondowoso?

${ }^{5}$ Firdhaus Hari Saputro A H \& Moch. Bagoes Pakarti, "Evaluasi Penerapan E-Learning Sebagai Media Pembelajaran Perkuliahan Online Bagi Mahasiswa Universitas Sahid Surakarta” Tekinfo: Jurnal Ilmiah Teknik Industri dan Informasi, Vol. 5 No. 2 (Mei 2017), 106.

${ }^{6}$ Wahyu Aji Fatma Dewi, "Dampak Covid-19 Terhadap Implementasi Pembelajaran Daring Di Sekolah Dasar” Edukatif: Jurnal Ilmu Pendidikan, Vol 2 No 1 (April 2020), 56.

${ }^{7}$ In Setyorini, "Pandemi Covid-19 Dan Online Learning: Apakah Berpengaruh Terhadap Proses Pembelajaran Pada Kurikulum-13?” Journal of Industrial Engineering \& Management Research, Volume :01, No :01 (June 2020), 96.

${ }^{8}$ Arja Kusuma, "Dukungan Perpustakaan Dalam Proses Pembelajaran Online Di Universitas Islam Negeri Sunan Kalijaga Pada Masa Pandemic Covid-19” LIBRIA Vol. 12, No. 1 (2020), 54. 202 | IQ (Ilmu Al-qur'an): Jurnal Pendidikan Islam| Volume 3 No.02 2020 


\section{Metode Penelitian}

Penelitian menggunakan metode studi kasus eksplorasi dan pendekatan penelitiannya menggunakan metode studi kasus kualitatif yang digunakan untuk mendapatkan informasi kendala dan akibat dari pandemic COVID-19 terhadap kegiatan proses belajar mengajar di MI At-Taqwa Bondowoso. Ukuran sampel didasarkan pada pencapaian kedalaman dan kekayaan deskripsi. Menurut Guetterman, ukuran sampel bukan masalah opini representative dan pandangan, tetapi lebih merupakan masalah kekayaan informasi. ${ }^{9}$ Dalam penelitian ini, responden merupakan guru kelas 2 MI At-Taqwa dan murid. Wawancara semi-terstruktur dilakukan dan daftar pertanyaan disusun untuk wawancara dikembangkan berdasarkan literatur terkait.

Metode pengumpulan menggunakan data primer melalui wawancara semi-terstruktur dan data sekunder diperoleh melalui data yang telah terpublikasi seperti artikel jurnal dan buku. Penelitian ini hanya terbatas oleh ukuran sampel murid kelas 2 MI At-Taqwa Bondowoso. Penelitian ini merupakan studi kasus eksplorasi sedangkan sampel dipilih menggunakan metode purposive sampling. Teknik purposive sampling dalam penelitian kualitatif adalah metode yang digunakan dengan tujuan untuk mencapai penelitian tertentu. Tidak ada batasan jumlah responden dalam membuat sampel purposive, dengan syarat informasi yang diinginkan bisa diperoleh. Creswell memberikan pengamatan dan beberapa rekomendasi ukuran sampel, yang berkisar tidak lebih dari empat hingga lima kasus dalam melakukan penelitian studi kasus. Dalam studi kasus para responden diwawancarai sehingga data yang telah diperoleh tidak ada lagi informasi baru atau tambahan. Berhubung penelitian ini dalam situasi pandemi covid-19 maka wawancara dilakukan di lakukan secara online. Semua narasumber yang di wawancara, dengan izin dan persetujuan yang ditanda tangani, kemudian direkam secara audio dan ditranskrip secara verbal.

\section{Hasil Penelitian dan Pembahasan}

\section{Sekilas tentang MI At-Taqwa Bondowoso}

MI At-Taqwa bondowoso adalah madrasah yang menggunakan perpaduan kurikulum yaitu yayasan At-Taqwa, kementrian agama dan departemen pendidikan nasional yang di dalamnya dikemas dengan pembelajaran yang islami dan menyenangkan.

${ }^{9}$ Agus Purwanto, Rudy Pramono, Masduki Asbari, Priyono Budi Santoso, Laksmi Mayesti Wijayanti, Choi Chi Hyun, Ratna Setyowati Putri, "Studi Eksploratif Terhadap Dampak Pandemi Covid-19 Terhadap Proses Pembelajaran Online Di Sekolah Dasar" EduPsyCouns: Journal of Education, Psychology and Counseling, Volume 2, Nomor 1 (2020), 3-4. 
Lembaga ini didirikan pada tahun ajar 1994-1995, tepat tanggal 16 Juli 1994 oleh KH. Masrur Masyhud R. (alm) sekaligus pimpinan pertama dari tahun 1994-2007 bersamaan dengan apel besar guru Agama se Wil. Pembantu Gubernur Besuki yang diresmikan oleh Bapak Kepala Kantor Departemen Agama Wilayah propinsi Jawa Timur, Drs. H. Mahmud Suyuthi, yang juga dihadiri oleh Bapak Bupati KDH. Tk. II Kab. Bondowoso, H. Agus Sarosa.

\section{Proses Pembalajaran Online di Tengah Pandemi Covid-19}

Proses pembelejaran dapat dikatakan berhasil jikalau tujuan pembelajaran itu telah tercapai. Berhasil atau tidaknya pencapaian tujuan pembelajaran tergantung pada proses pembelajaran yang dijalani oleh siswa. Menurut Asmani ada dua indikator yang dapat dijadikan sebagai acuan keberhasilan proses belajar yaitu daya serap terhadap pelajaran dan perubahan dari perilaku siswa. ${ }^{10}$

Menuntut ilmu diwajikan bagi seluruh umat islam baik kapan saja dan di mana saja. Sesuai dengan hadist nabi Muhammad SAW yang berbunyi Artinya :" Dari Anas bin Malik Radhiyallahu'anhu, ia berkata : "Rasulullah Shallallahu'alaihi wa sallam bersabda : “Menuntut ilmu itu adalah kewajiban bagi setiap Muslim.” (H.R. Ibnu Majah) maksud dari Hadist ini adalah bahwa seluruh umat islam baik laki-laki maupun perumpuan hukumnya wajib untuk menuntut ilmu, meskipun berada di masa pandemi covid-19 seperti ini. ${ }^{11}$

Pembelajaran merupakan sebuah proses interaksi edukatif antara peserta didik, guru dan lingkungan yang telah melibatkan berbagai komponen pembelajaran dengan tujuan untuk mencapai pembelajaran yang telah di konsep sedemikian rupa. Menurut Unang Wahidin dan Ahmad Syaefuddin, bahwa proses pembelajaran merupakan sebuah sistem yang disebut sistem pembelajaran. Adapun komponen sistem pembelajaran yang dimaksud yaitu: (a) Tujuan pendidikan dan pembelajaran; (b) Perencanaan pembelajaran; (c) Peserta didik; (d) Guru; (e) Metode pembelajaran; (f) Media pembelajaran; dan (g) Evaluasi pembelajaran. Dalam interaksi edukatif setiap guru dituntut untuk dapat mengelola komponen-komponen sistem pembelajaran tersebut.

Interaksi edukatif antara peserta didik, guru dan lingkungan merupakan interaksi yang diharapkan untuk mencapai tujuan pembelajaran. Di dalam interaksi edukatif, peserta didik dapat melakukan berbagai proses pembelajaran melalui berbagai cara, diantaranya: (a) Dengan

\footnotetext{
${ }^{10}$ Ibadullah Malawi, AA Tristiar, "Pengaruh Konsentrasi Dan Kemampuan Berpikir Kritis Terhadap Prestasi Belajar Ips Siswa Kelas V Sdn Manisrejo I Kabupaten Magetan” Premiere Educandum: Jurnal Pendidikan Dasar dan Pembelajaran, Vol. 3, No. 2 (2013), 119.

11 Ashabul Kahfi, "Tantangan Dan Harapan Pembelajaran Jarak Jauh Di Masa Pandemi Covid 19" Dirasah: Jurnal Pemikiran dan Pendidikan Dasar Islam, Vol. 03 No.2 (Agustus 2020), 141. 204 | IQ (Ilmu Al-qur'an): Jurnal Pendidikan Islam| Volume 3 No.02 2020
} 
cara membaca; (b) mendengarkan; (c) menulis; (d) menulis kembali materi pembelajaran; (e) memperhatikan; (f) mengamati; (g) bertanya; (h) mencari; (i) menghubungkan satu materi dengan materi pembelajaran lainnya; (j) mengkomunikasikan; dan (k) melakukan. Berbagai macam cara belajar tersebut dapat dilakukan oleh peserta didik, sehingga siswa tidak ada lagi alasan tidak bisa belajar.

Sarana dan iklim pembelajaran terkait juga dengan kualitas pembelajaran, berupa efektif tidaknya proses belajar mengajar. Kualitas pembelajaran dipengaruhi antara lain oleh: (a) Kompetensi (kemampuan dasar) guru yang dipersyaratkan; (b) Banyak sedikitnya jumlah peserta didik; (c) Suasana belajar yang memberi kesempatan kepada siswa untuk terlibat dalam proses pembelajaran. Suasana pembelajaran yang demokratis memungkinkan adanya kebebasan siswa untuk berpendapat, bertanya dan berdialog; (d) Tersedianya fasilitas dan sumber belajar yang lain (buku pelajaran, alat peraga dan lain-lain); dan (e) Karakteristik sekolah itu sendiri, berkaitan dengan kedisiplinan sekolah, letak geografis sekolah, lingkungan dan suasana sekolah, dan estetika/kenyamanan sekolah. ${ }^{12}$

Dalam masa pandemi Covid-19 ini jika kegiatan belajar mengajar secara langsung atau tatap muka tetap dilaksanakan maka akan banyak menimbulkan kemudharatan. Jadi untuk mencegah penularan virus ini sekolah-sekolah harus tetap melaksanakan kegiatan belajar mengajar dengan cara daring atau online. Sebagaimana dalam Undang- Undang No 20 Tahun 2003 tentang Sistem Pembelajaran Nasional (Sisdiknas), yang diartikan dengan Pembelajaran Jarak Jauh (PPJ) merupakan pembelajaran yang peserta didiknya terpisah dari pendidik serta pembelajarannya memakai bermacam sumber belajar lewat teknologi komunikasi, data, serta media yang lain. Organisasi PBB yang mengurusi pendidikan, keilmuan, dan kebudayaan UNESCO menyebutkan, lebih dari 1,5 miliar pelajar di dunia tidak bisa belajar di sekolah akibat virus ini. ${ }^{13}$

Pembelajaran online dapat menghubungkan pembelajar (peserta didik) dengan sumber belajarnya (database, pakar/instruktur, perpustakaan) yang secara fisik berjauhan atau bahkan terpisah namun dapat saling berkomunikasi, berinteraksi atau berkolaborasi (secara langsung/synchronous dan secara tidak langsung/asynchronous). Pembelajaran online adalah sebuah bentuk pembelajaran/pelatihan yang dilakukan jarak jauh dengan memanfaatkan teknologi telekomunikasi informasi, misalnya internet, CD-ROOM (secara langsung dan tidak

${ }^{12}$ Unang Wahidin, "Implementasi Literasi Media Dalam Proses Pembelajaran Pendidikan Agama Islam Dan Budi Pekerti” Edukasi Islami: Jurnal Pendidikan Islam, Vol : 07 No: 02 (2018), 231.

${ }^{13}$ Zainal Abidin, Rumansyah, Kurniawan Arizona, "Pembelajaran Online Berbasis Proyek Salah Satu Solusi Kegiatan Belajar Mengajar Di Tengah Pandemi Covid-19" Jurnal Ilmiah Profesi Pendidikan, Volume 5, No 1 (Mei 2020), 65. 
langsung). ${ }^{14}$ Namun, sistem pembelajaran yang dilaksanakan secara jarak jauh melalui sistem internet ini juga menjadi kendala bagi yang menjalankan. keadaan guru dan siswa yang terpisah saat melaksanakan pembelajaran menjadikan para guru kesulitan untuk mengontrol dan menjaga iklim belajar yang disebabkan keterbatasan dalam ruang virtual. Dampak lainnya yang dirasakan para guru dan murid yaitu tidak semua guru dan murid mampu mengaplikasikan berbagai macam fitur dan teknologi media social sebagai fasilitas belajar. Karna sebenarnya kebanyakan dari mereka pada awalnya sangat memerlukan pendampingan dan pelatihan. ${ }^{15}$

Beberapa persyaratan yang dibutuhkan bagi peserta didik dalam melaksanakan pembelajaran dengan sistem online, yakni (1) literasi teknologi informasi dan komunikasi, dalam artian peserta didik harus memiliki kemampuan dalam memahami teknologi informasi dan komunikasi yang digunakan dalam mendukung keberlangsungan pembelajaran online, baik teknologi informasi dan komunikasi yang digunakan untuk mencari dan menemukan informasi yang dibutuhkan dalam proses pembelajaran online, (2) Indevendency, dengan artian bahwa dalam sistem pembelajaran online sangat ditentukan oleh kemandirian peserta didik terutama dalam mencari berbagai macam sumber informasi yang dibutuhkan dalam proses pembelajaran online tersebut, (3) Creativity dan critical thinking, dalam artian peserta didik dituntut untuk bertindak kreatif supaya tidak hanya mengandalkan sumber informasi yang disediakan oleh guru, namun peserta didik juga perlu mencari dan menemukan sumber-sumber infomasi lain yang relevan dengan tema yang berkaitan dengan pembelajaran. ${ }^{16}$

Menurut Agus, dkk dalam penelitiannya yang berjudul "Studi Eksploratif Dampak Pandemi COVID-19 Terhadap Proses Pembelajaran Online di Sekolah Dasar" dampak COVID-19 terhadap proses pembelajaran online di sekolah dasar berdampak terhadap siswa, orang tua dan guru itu sendiri. Beberapa dampak yang dirasakan murid yaitu murid belum ada budaya belajar jarak jauh karena selama ini sistem belajar dilaksanakan adalah melalui tatap muka, murid terbiasa berada di sekolah untuk berinteraksi dengan teman-temannya, bermain dan bercanda gurau dengan teman-temannya serta bertatap muka dengan para gurunya, dengan adanya metode pembelajaran jarah jauh membuat para murid perlu waktu untuk beradaptasi dan mereka menghadapi perubahan baru yang secara tidak langsung akan mempengaruhi daya

\footnotetext{
${ }^{14}$ Zainal Abidin, Rumansyah, Kurniawan Arizona, "Pembelajaran Online Berbasis Proyek Salah Satu Solusi Kegiatan Belajar Mengajar Di Tengah Pandemi Covid-19”, 65

15 Sarah Busyra \& Lutfiah Sani, "Kinerja Mengajar Dengan Sistem Work From Home (WFH) Pada Guru Di SMK Purnawarman Purwakarta” Ilmu Al-Qur'an (IQ) Jurnal Pendidikan Islam, Volume 3 No. 01 (2020), 6.

16 "Dukungan Perpustakaan Dalam Proses Pembelajaran Online Di Universitas Islam Negeri Sunan Kalijaga Pada Masa Pandemic Covid-19," 54.

206 | IQ (Ilmu Al-qur'an): Jurnal Pendidikan Islam| Volume 3 No.02 2020
} 
serap belajar mereka. Dampak terhadap orang tua yaitu kendala yang dihadapi para orang tua adalah adanya penambahan biaya pembelian kuot a internet bertambah, teknologi online memerlukan koneksi jaringan ke internet dan kuota oleh karena itu tingkat penggunaaan kuota internet akan bertambah dan akan menambah beban pengeluaran orang tua. Dampak yang dirasakan guru yaitu tidak semua mahir menggunakan teknologi internet atau media sosial sebagai sarana pembelajaran, beberapa guru senior belum sepenuhnya mampu menggunakan perangkat atau fasilitas untuk penunjang kegiatan pembelajaran online dan perlu pendampingan serta pelatihan terlebih dahulu. Jadi, dukungan dan kerjasama orang tua demi keberhasilan pembelajaran sangat dibutuhkan. Komunikasi guru dan sekolah dengan orang tua harus terjalin dengan lancar. ${ }^{17}$

Ibnu Khaldun di dalam Muqaddimah-nya memberikan arahan tentang pentingnya mengajarkan al-Qur'an pada anak. Ia menjelaskan bahwa mengajari al-Qur'an kepada anak merupakan pondasi awal untuk mempelajari semua metode pembelajaran yang ada di berbagai negara Islam. Hal ini juga menjadi syiar agama yang bisa mengokohkan akidah dan menancapkan keimanan pada diri anak. ${ }^{18}$ Oleh karena itu MI At-Taqwa menggunakan sistem pembelajaran metode Yanbu'a untuk meningkatkan kemampuan siswa dalam membaca alqur'an secara baik dan benar. Ide ini pertama kali dicetuskan oleh oleh ketua yayasan AtTaqwa yakni KH. Imam Barmawi, adapun alasan untuk menggunakan metode yanbu'a dikarenakan metode ini berbeda dengan metode yang lain, metode ini bukan hanya sekedar metode tapi juga thoriqoh sambung sanad bacaan hingga sampai ke Rasulullah. ${ }^{19}$

Pembelajaran metode yanbu'a di MI At-Taqwa merupakan kegiatan pembuka atau kegiatan awal sebelum memulai pembelajaran, jadi membaca yanbu'a plus asmaul husna. Proses pembelajaran metode Yanbu'a murid kelas 2 MI At-Taqwa bondowoso selama pandemi covid-19 guru menggunakan metode daring/online yang telah disepakati bersama oleh guru, murid beserta wali murid dan mereka telah sepakat menggunakan aplikasi google class room. Google Classroom adalah sebuah aplikasi yang disediakan oleh Google sehingga memungkinkan terciptanya ruangan kelas dalam dunia maya (pembelajaran berbasis online). Selain itu, aplikasi ini menjadi salah satu sarana dalam yag memudahkan siswa untuk mengumpulkan tugas tanpa harus mencetaknya dalam bentuk hardcopy. Google Classroom

${ }^{17}$ Wahyu Aji Fatma Dewi, Dampak Covid-19 terhadap Implementasi Pembelajaran Daring di Sekolah Dasa, Edukatif : Jurnal Ilmu Pendidikan Vol 2 No 1 April 2020, 59-60.

${ }_{18}$ Novan Ardy Wiyani, "Manajemen Program Parenting Bimbingan Baca-Tulis Al-Qur'an Dengan Metode Yanbu'a Bagi Orang Tua Di Tk Nurul Hikmah Kecamatan Tonjong Kabupaten Brebes" ThufuLA: Jurnal Inovasi Pendidikan Guru Raudhatul Athfal, Vol. 5 No. 2 (2018),231.

${ }^{19}$ Wawancara dengan Nur Khotim, S.Pd.I (waka humas MI At-Taqwa) 
dianggap sebagai salah satu platform terbaik di luar sana untuk memberikan kemudahan bagi siswa dan meningkatkan alur kenerja guru. Aplikasi ini telah menyediakan satu set fitur canggih serta menjadikannya alat ideal untuk digunakan siswa. Google Classroom telah membantu pengajar dalam menghemat waktu, guru dapat mendesain ruang diskusi dan pemberian materi secara daring kepada siswa sebagai tugas mandiri dengan keleluasaan waktu agar kelas tetap kondusif, serta dengan aplikasi ini guru dan siswa dapat berinteraksi dengan mudah di dunia maya. Akun ini tersedia bagi siapa saja yang memiliki Google Apps for Education, rangkaian produktivitas gratis alat termasuk Gmail, Drive, dan Dokumen. ${ }^{20}$

Kelebihan Akses yang dimiliki oleh Google Classroom tentunya juga memerlukan koneksi internet yang bagus, dan pengguna harus memiliki akun Gmail sebagai syarat pendaftaran menggunakan akses Google Classroom. Pada mulanya bagi sebagian siswa MI AtTaqwa Bondowoso masih belum familier terhadap aplikasi ini, sehingga sosialisasi sangatlah dibutuhkan agar siswa mampu menggunakan aplikasi ini secara efektif.

Media atau Aplikasi kedua yang telah disepakati oleh guru dan siswa kelas 2 MI AtTaqwa Bondowoso yakni menggunakan video call dari aplikasi watshapp. Aplikasi ini sekarang telah memfasilitasi serta mendukung untuk mengirim dan menerima berbagai macam media: teks, foto, video, dokumen, dan lokasi, juga panggilan suara. Pesan dan panggilan juga diamankan dengan enkripsi end-to-end, yang berarti tidak ada pihak ketiga termasuk WhatsApp yang dapat membaca pesan atau mendengar panggilan. Di balik setiap keputusan produk terdapat keinginan agar orang-orang dapat berkomunikasi di mana pun di seluruh dunia tanpa batasan. WhatsApp telah digandrungi oleh banyak orang dan menjadi salah satu aplikasi wajib yang terinstal pada smartphone. Bahkan ada beberapa orang yang memiliki double account untuk aplikasi ini. Selain untuk kebutuhan pribadi, WhatsApp juga merambah ke dunia bisnis dengan munculnya aplikasi baru yakni WhatsApp business. Guru kelas 2 MI At-Taqwa Bondowoso mengontrol tadarrus siswa dengan mengirim audio pembelajaran yanbu'a (dari ustadz/ustadzah khusus yanbu'a) dan nantinya guru al-qur'an akan video call siswa satupersatu dengan tujuan agar bisa mendampingi secara personal sekaligus mengetahui perkembangan siswa dalam mengaji yanbu'a meskipun hanya melalui online.

Adapaun kendala yang dialami murid dalam pembelajaran metode yanbu'a menggunkan sistem online dalam situasi pandemi covid-19, antara lain: guru dan siswa terkendala dengan jaringan internet, kebosanan siswa karena berada di rumah terus sehingga

${ }^{20}$ Muhammad Taufiqurrahman, "Perkuliahan Daring Mata Kuliah Ilmu Pendidikan Islam Pada Masa Darurat Covid-19, Ta'dibuna: Jurnal Pendidikan Islam," 215.

208 | IQ (Ilmu Al-qur'an): Jurnal Pendidikan Islam| Volume 3 No.02 2020 
tidak bisa berinterkasi dengan teman yang lain secara langsung, ada sebagian siswa yang terkendala dengan alat telekomunikasi karena di usia mereka yang masih kelas 2 MI kebanyakan dari mereka tidak memiliki alat telekomunikasi sendiri dan meminjam dari orang tuanya sedangkan kesibukan setiap orang tua berbeda akhirnya saat guru al-qur'an menghubungi siswa untuk mengaji dan setoran yanbu'a secara online akhirnya banyak yang tidak terlaksana dan berjalan kurang maksimal.

Berdasarkan data di atas, dapat disimpulkan bahwa penggunaan aplikasi WhatsApp group dalam pembelajaran metode Yanbu'a kelas 2 MI At-Taqwa Bondowoso lebih diminati siswa karena kemudahan akses, penggunaan kuota yang tidak terlalu besar, tampilan yang menarik dan besaran file tidak terlalu berat. Sehingga peneliti berasumsi bahwa aplikasi WhatsApp ini sudah terinstal pada perangkat siswa dan juga bisa dianggap sebagai kebutuhan yang digunakan sehari-hari, meskipun pembelajaran yanbu'a dengan sistem online memiliki kendala tapi kecenderungan siswa dalam menggunakan WhatsApp sebagai sarana pembelajaran daring ini cukup tinggi, karena sudah terbiasa dan sering digunakan dalam keseharian.

\section{Proses Pembelajaran Metode Yanbu'a di MI At-Taqwa Bondowoso}

Secara etimologis, metode diambil dari bahasa Yunani yakni metha yang berarti lewat atau melalui, serta hodos yang maknanya cara atau jalan. Sehingga dapat diartikan bahwa metode ialah sebuah cara atau jalan yang mesti ditemouh dalam rangka untuk mencapai sasaran. Metode memiliki peranan utama bagi kegiatan pembelajaran, karena metode merupakan fasilitator terkait pendekatan dan model pembelajaran. Sebagaimana yang disampaikan oleh Nana Sudjana bahwa metode pembelajaran merupakan gaya guru dalam berinteraksi dengan murid disaat pembelajaran sedang berlangsung. ${ }^{21}$

Yanbu'a adalah sebuah kitab (metode) untuk mempelajari baca tulis dan menghafal AlQuran dengan cepat, mudah dan benar. Kelebihan dari metode ini dirancang dengan rasm Ustmani menggunakan tanda baca waqof yang sudah banyak dipelajari di negara-negara islam dan utamanya di Negara arab. Adapun Rasm Ustmani ini sendiri merupakan tata cara atau kaidah penelitian huruf-huruf dan kata-kata Al-Qur'an yang telah disetujui pada masa Khalifah Ustman dan dipedomani oleh tim penyalin Al Qur'an yang dibentuk oleh Zaid bin Tsabit dan Abdullah Ibn Al Zubair Ibn Hasyim. Metode Yanbu'a adalah suatu metode pembelajaran

\footnotetext{
${ }^{21}$ Agus Nur Qowim, "Metode Pendidikan Islam Perspektif Al-Qur'an” Ilmu Al-Qur'an (IQ) Jurnal Pendidikan Islam, Volume 3 No. 01 (2020), 37.
} 
membaca, menulis dan menghafal Al-Qur'an dengan cepat, tepat, benar serta tidak putus-putus sesuai dengan makhrojul huruf dan ilmu tajwid yang disusun secara systematis terdiri dari tujuh jilid, meskipun metode ini masih terdapat kekurangan yaitu belum terealisasinya rasm usmani secara penuh. $^{22}$

Pengambilan nama yanbu'a yang memiliki arti sumber, dan ini mengambil dari kata yanbu'ul qur'an yang artinya sumber al-qur'an, nama yang sangat digemari dan disenangi oleh seorang guru besar al-qur'an al-Muqri si mbah KH. M. Arwani Amin, yang silsilah keturunannya sampai pangeran diponegoro. ${ }^{23}$ Penyusunan buku metode yanbu'a di prakarsai oleh tiga pengasuh pondok tahfidz yanbu'ul qur'an putra KH. Arwani Amin Al Kudsy (Alm), KH. M. Ulin Nuha Arwani, KH. Ulil Albab Arwani dan KH. Manshur Maskan (Alm) dan tokoh lain diantaranya: KH. Sya'roni Ahmadi (Kudus), dan KH. Amin Sholeh (Jepara), Ma'mun Muzayyin (Kajen Pati), KH. Sirojuddin (Kudus) dan KH. Busyro (Kudus) beliau adalah Mutakhorrijin Pondok Tahfidh Yanbu'ul Qur'an yang tergabung dalam majelis "Nuzulis Sakinah" Kudus.

Cara pembelajaran Yanbu'a yaitu (1) Musyafahah yaitu guru membacakan terlebih dahulu kemudian santri menirukan. Dengan cara inilah guru dapat mencontohkan dan menerapkan bacaan huruf dengan benar melalui lidahnya. Kemudian santri langsung dapat melihat dan menyaksikan praktek keluarnya huruf dari lidah guru yang ditirukannya. (2) Ardhul Qira'ah yaitu santri membaca di depan guru sedangkan guru menyimak dengan baik. Lalu cara ini dikalangan pesantren dikenal dengan sebutan sorogan. Dengan cara ini akan memudahkan guru dalam mengetahui dan membenarkan bacaan santri yang salah. (3) Pengulangan yaitu guru mengulang-ulang bacaan, sedangkan santri menirukannya kata demi kata atau kalimat demi kalimat, juga secara berulang-ulang hingga terampil dan dianggap benar oleh sang guru Yanbu'a. ${ }^{24}$

Dari berbagai sistem penyampaian materi belajar Al-Qur'an yang ada saat ini, semuanya menawarkan dan menyajikan penyampaian materi belajar yang memudahkan siswa dalam menerima pesan pembelajaran, terkhusus dalam pembelajaran Al-Qur'an. Akan tetapi kebanyakan dari lembaga pendidikan Al-Qur'an yang ada tidak meninggalkan teori

${ }^{22}$ Muslikah Suriah, “Metode Yanbu'a Meningktakan Kemampuan Membaca Al-Quran Pada Kelompok B-2 RA Permata Hati Al-Mahali Bantul” Jurnal Pendidikan Madrasah, Volume 3 Nomor 2 (November 2018), 293.

${ }^{23}$ Siti Ayamil Choliyah, "Peningkatan Prestasi Belajar Membaca Al-Qur'an Dengan Metode Yanbu'A" MUDARRISA: Jurnal Kajian Pendidikan Islam, Vol. 7, No. 2, (Desember 2015), 160-61.

${ }^{24}$ Aya Mamlu'ah, Devy Eka Diantika, "Metode Yanbu’a Dalam Penanaman Kemampuan Membaca Huruf Hijaiyah Pada Santri TPQ At-Tauhid Tuban,” Al Ulya: Jurnal Pendidikan Islam, Volume 3 Nomor II (Desember 2018), 113.

210 | IQ (Ilmu Al-qur'an): Jurnal Pendidikan Islam| Volume 3 No.02 2020 
musyafahah sebagai sistem pembelajaran paling bagus dalam mencapai hasil yang maksimal. Hal ini dikarenakan dari penyampaian materi yang begitu mudah sehingga siswa dapat menirukan secara langsung apapun yang dibaca oleh guru secara perlahan melalui lidahnya, kemudian guru juga dapat mengoreksi secara langsung baik makharijul huru, tajwid atau lainya, sampai siswa dapat secara benar membaca Al-Qur'an.

Penerapan metode Yanbu'a diharapkan meningkatkan kemampuan siswa membaca alqur'an secara baik dan benar, bahwa Efektivitas metode pembelajaran dapat dilihat dari beberapa aspek, antara lain adalah: (1) Adanya produktivitas metode pembelajaran, (2) Target dan tujuan pembelajaran yang tercapai dalam waktu yang singkat, (3) kepuasaan kerja, yang berarti tingkat ketercapaian metode pembelajaran tersebut sesuai dengan tujuan yang telah ditetapkan, (4) Intensitas emosi, apakah siswa merasa semangat, antusias, bahagia, dan nyaman menggunakan metode pembelajaran, dan tingkat kehadiran yang tinggi, (5) Peran guru dalam Kegiatan Belajar Mengajar.

\section{Kesimpulan}

Dari hasil penelitian yang dilakukan oleh peneliti mengenai dampak pembelajaran online di tengah pandemi covid-19 terhadap proses pembelajaran metode yanbu'a di kelas 2 MI At-taqwa bondowoso, peneliti menemukan fakta bahwa pembelajaran metode yanbu'a di kelas 2 MI At-taqwa bondowoso sebelum adanya covid 19 dilaksanakan setiap pagi sebelum memulai pembelajaran diawali dengan membaca asmaul husna dilanjut pembelajaran al-qur'an menggunakan metode yanbu'a. Akan tetapi semenjak adanya covid-19 sistem pembelajaran alqur'an dengan metode yanbu'a hanya dapat dilaksanakan melalui online, seperti guru mengirimkan video melalui Whatapp group lalu siswa belajar sendiri dirumah, setelah itu guru akan menghubungi siswa satu persatu melalui video call Whatapp. Akan tetapi dalam proses pembelajaran seperti ini tidak berjalan dengan lancar dalam artian sebagian siswa tidak aktif untuk menyetorkan hasil bacaannya dikarenakan adanya kendala jaringan, tidak adanya kuota, siswa tidak memiliki alat komunikasi atau handpohne sendiri, oleh karenanya tujuan dan target yang ingin dicapai oleh MI At-Taqwa bondowoso seperti cita-cita semula adalah siswa mampu membaca al-Quran dengan baik dan benar antara lain berupa makhorijul huruf, sifat-sifat huruf dan fashohah yang tepat banyak mengalami kendala akibat dari pembelajaran online.

\section{Saran}

Berdasarkan hasil penelitian, pembahasan serta kesimpulan yang telah dijelaskan, maka peneliti dapat mengajukan beberapa saran. Pertama, bagi subjek penelitian, peneliti 
mengharapkan agar guru selalu memotivasi siswa supaya prestasi dan program yang telah dilaksanakan tetap berjalan dengan baik, bagi siswa kelas 2 MI At-Taqwa Bondowoso tetap semangat mengaji dan setoran Yanbu'a kepada guru kelas walaupun dalam kondisi ini supaya tujuan dari pembelajaran yanbu'a ini tetap berjalan dengan baik. Kedua, bagi peneliti selanjutnya yang ingin meneliti dengan tema ini agar mengkaji dari segi hasil perbandingan siswa dalam belajar metode yanbu'a sebelum dan sesudah melakukan pembelajaran online.

\section{Daftar Pustaka}

Abidin, Zainal, Rumansyah, dan Kurniawan Arizona. "Pembelajaran Online Berbasis Proyek Salah Satu Solusi Kegiatan Belajar Mengajar Di Tengah Pandemi Covid-19” Jurnal Ilmiah Profesi Pendidikan, Volume 5, No 1 (Mei 2020).

Busyra, Sarah dan Lutfiah Sani. "Kinerja Mengajar Dengan Sistem Work From Home (WFH) Pada Guru Di SMK Purnawarman Purwakarta” Ilmu Al-Qur'an (IQ) Jurnal Pendidikan Islam, Vol. 3 No. 01 (2020).

Choliyah, Siti Ayamil. "Peningkatan Prestasi Belajar Membaca Al-Qur'an Dengan Metode Yanbu'a” MUDARRISA: Jurnal Kajian Pendidikan Islam, Vol. 7, No. 2, (Desember 2015).

Dewi, Wahyu Aji Fatma. "Dampak Covid-19 Terhadap Implementasi Pembelajaran Daring Di Sekolah Dasar” Edukatif: Jurnal Ilmu Pendidikan, Vol 2 No 1 (April 2020).

Kahfi, Ashabul. "Tantangan Dan Harapan Pembelajaran Jarak Jauh Di Masa Pandemi Covid 19" Dirasah: Jurnal Pemikiran dan Pendidikan Dasar Islam, Vol. 03 No.2 (Agustus 2020).

Kusuma, Arja. "Dukungan Perpustakaan Dalam Proses Pembelajaran Online Di Universitas Islam Negeri Sunan Kalijaga Pada Masa Pandemic Covid-19” LIBRIA Vol. 12, No. 1 (54): Juni 2020.

Malawi, Ibadullah, dan AA Tristiar. "Pengaruh Konsentrasi Dan Kemampuan Berpikir Kritis Terhadap Prestasi Belajar Ips Siswa Kelas V Sdn Manisrejo I Kabupaten Magetan” Premiere Educandum: Jurnal Pendidikan Dasar dan Pembelajaran, Vol. 3, No. 2 (2013).

Mamlu'ah, Aya, dan Devy Eka Diantika. "Metode Yanbu'a Dalam Penanaman Kemampuan Membaca Huruf Hijaiyah Pada Santri TPQ At-Tauhid Tuban," Al Ulya: Jurnal Pendidikan Islam, Volume 3 Nomor II (Desember 2018).

Purnomo, Halim, Firman Mansir, Tumin, dan Suliswiyadi. "Pendidikan Karakter Islami Pada 
Online Class Management Di SMA Muhammadiyah 7 Yogyakarta Selama Pandemi Covid-19” Jurnal Tarbiyatuna, Vol. 11 No. 1 (2020).

Purwanto, Agus, Rudy Pramono, Masduki Asbari, Priyono Budi Santoso, Laksmi Mayesti Wijayanti, Choi Chi Hyun, dan Ratna Setyowati Putri. "Studi Eksploratif Terhadap Dampak Pandemi Covid-19 Terhadap Proses Pembelajaran Online Di Sekolah Dasar" EduPsyCouns: Journal of Education, Psychology and Counseling, Vol. 2, Nomor 1 (2020).

Qowim, Agus Nur. "Metode Pendidikan Islam Perspektif Al-Qur'an” Ilmu Al-Qur'an (IQ) Jurnal Pendidikan Islam, Vol. 3 No. 01 (2020)

Saputro, Firdhaus Hari, dan Moch. Bagoes Pakarti. "Evaluasi Penerapan E-Learning Sebagai Media Pembelajaran Perkuliahan Online Bagi Mahasiswa Universitas Sahid Surakarta” Tekinfo: Jurnal Ilmiah Teknik Industri dan Informasi, Vol. 5 No. 2 (Mei 2017).

Setyorini, In. "Pandemi Covid-19 Dan Online Learning: Apakah Berpengaruh Terhadap Proses Pembelajaran Pada Kurikulum-13?" Journal of Industrial Engineering \& Management Research, Volume :01, No :01 (Juni 2020).

Soebahar, Abd. Halim. Matriks Pendidikan Islam. Yogyakarta: Pusataka Marwa, 2009.

Suriah, Muslikah. "Metode Yanbu'a Meningktakan Kemampuan Membaca Al-Quran Pada Kelompok B-2 RA Permata Hati Al-Mahali Bantul” Jurnal Pendidikan Madrasah, Volume 3 Nomor 2 (November 2018).

Taufiqurrahman, Muhammad. "Perkuliahan Daring Mata Kuliah Ilmu Pendidikan Islam Pada Masa Darurat Covid-19”, Ta'dibuna: Jurnal Pendidikan Islam Vol. 9, No. 2 (Oktober 2020).

Wahidin, Unang. "Implementasi Literasi Media Dalam Proses Pembelajaran Pendidikan Agama Islam Dan Budi Pekerti” Edukasi Islami: Jurnal Pendidikan Islam, Vol : 07 No: 02 (2018).

Wiyani, Novan Ardy. “Manajemen Program Parenting Bimbingan Baca-Tulis Al-Qur'an Dengan Metode Yanbu'a Bagi Orang Tua Di Tk Nurul Hikmah Kecamatan Tonjong Kabupaten Brebes" ThufuLA: Jurnal Inovasi Pendidikan Guru Raudhatul Athfal, Vol. 5 No. 2 (2018). 
Fatia Inast Tsuroya

214 | IQ (Ilmu Al-qur'an): Jurnal Pendidikan Islam| Volume 3 No.02 2020 